\title{
An In vitro Dose Optimization of Exogenous Fibrolytic Enzymes in Total Mixed Ration for Crossbred Cows
}

\author{
P.M. Lunagariya ${ }^{1 *}$, S.V. Shah ${ }^{1}$, B.R. Devalia ${ }^{2}$, A.C. Patel ${ }^{3}$ and P.R. Pandya ${ }^{2}$
}

${ }^{1}$ Livestock research Station, ${ }^{2}$ Department of Animal Nutrition Research, ${ }^{3}$ Department of Animal Genetics \& Breeding, College of Veterinary Science \& Animal Husbandry, Anand Agricultural University, Anand, Gujarat, India

*Corresponding author

\begin{tabular}{|c|}
\hline Keywords \\
\hline $\begin{array}{l}\text { Exogenous fibrolytic } \\
\text { enzymes, in vitro } \\
\text { digestibility, } \\
\text { Metabolizable energy, } \\
\text { Microbial biomass } \\
\text { production, Total gas } \\
\text { production }\end{array}$ \\
\hline Article Info \\
\hline $\begin{array}{l}\text { Accepted: } \\
04 \text { September } 2018 \\
\text { Available Online: } \\
10 \text { October } 2018\end{array}$ \\
\hline
\end{tabular}

\section{Keywords}

Exogenous fibrolytic enzymes, in vitro digestibility,

Microbial biomass

production, Total gas production

Accepted:

Available Online:

10 October 2018

\section{A B S T R A C T}

An experiment was conducted to evaluate the levels of exogenous fibrolytic enzymes (EFE) on in vitro digestibility of dry matter (DM) and organic matter (OM), net gas production (NGP), metabolizable energy (ME) content, microbial biomass production (MBP) and efficiency of microbial biomass production (EMP). The total mixed ration (TMR) was prepared using sorghum hay and groundnut straw and compound concentrate mixture @ 30, 30 and 40\%, respectively, to meet nutrient requirement of cow $(500 \mathrm{~kg})$ producing $12 \mathrm{~kg}$ fat corrected milk. The cellulase and xylanase was incorporated @ 0+0, $1000+2000,1000+3000,1000+4000,2000+4000,2000+6000,2000+8000,3000+6000$, $3000+9000, \quad 3000+12000, \quad 4000+8000, \quad 4000+12000, \quad 4000+16000, \quad 5000+10000$, $5000+15000,5000+20000,6000+12000,6000+18000$ and $6000+24000 \mathrm{IU} / \mathrm{kg}$ TMR. The TMR with different levels of cellulase and xylanase were in vitro incubated to ascertain their effect on digestibility, gas production, and nutritive values. The significantly $(\mathrm{p}<0.05)$ higher and optimum in vitro digestibility of DM (66.243\%) and OM (66.56\%), NGP (76.48 ml/500 mg TMR) and ME (7.41 MJ/kg DM) were observed at 3000+12000 cellulase and xylanase IU/kg TMR supplementation, whereas MBP $(146.73 \mathrm{mg} / 500 \mathrm{mg}$ TMR) and EMP (44.02) were significantly $(\mathrm{p}<0.05)$ higher and optimum at C4X12 and C5X15 TMR, respectively. The MBP (145.86 mg/500 mg TMR) and EMP (43.83) also better at C3X12 TMR. The levels of cellulase $3000+$ xylanase $12000 \mathrm{IU} / \mathrm{kg}$ TMR were found suitable for further in vivo study in crossbred cows.

\section{Introduction}

The digestion of forage in ruminants occurs through the microbial fermentation. The microbial digestion allowed ruminants to better unlock the unavailable energy in the plant cell wall components than other herbivores (Van Soest, 1994; Krause et al., 2003). Thus ruminant animals are able to convert low nutritive and resistant lignocellulosic biomass to milk, meat, wool and hides (Weimer et al., 2009) owing to 
ruminal microorganisms that synthesize and secrete $\beta$ 1-4 cellulase enzyme complex. However, most forage plants are high in cell walls and low in nitrogen $(\mathrm{N})$ and energy content (Romney and Gill, 2000), hence are not utilized efficiently even by ruminants. Though fibrous components in forages is importance for salivation, rumen buffering and efficient rumen fermentation (Mertens, 1997) only 10 to $35 \%$ of energy intake is utilize as net energy (Varga and Kolver, 1997). This is owing to incomplete ruminal digestion of plant cell walls (Krause et al., 2003). An incorporation of exogenous fibrolytic enzymes (EFE) in feeds is one of the bio-processing tool to improve the energy availability of feeds in dairy cattle.

Positive effects of EFE include direct fibre hydrolysis, palatability improvement, changes in gut viscosity, complimentary and synergistic action with ruminal enzymes, change in the site of digestion (Beauchemin and Rode, 1996), increase in rumen bacterial colonization of the fibre substrate (Wang et al., 2012), altering and thinning of fiber cell wall (van de Vyver and Cruywagen, 2013). The feeding EFE supplemented diet were reported to improve the digestibility of dry matter (DM), organic matter (OM), crude fiber, neutral detergent fiber (NDF), cellulose and hemicellulose in dairy animals (Miachieo and Thakur, 2007; Rajamma et al., 2014; Morsy et al., 2015). An in vivo study need living animals which is expensive and time consuming, where as an in vitro to evaluation of the effect of EFE on digestibility and nutritive value of feed is cheaper, faster and more controllable (Makkar, 2004).

It was hypothesized that EFE improve the fermentation parameters of feed. The experiment was conducted to examined the effect of supplementing various levels of EFE in TMR on in vitro digestibility, net gas production (NGP), metabolizable energy (ME) content, and microbial biomass production (MBP) and efficiency of microbial biomass production (EMP).

\section{Materials and Methods}

The study was conducted at Animal Nutrition Research Department, College of Veterinary Science and Animal Husbandry, Anand Agricultural University, Anand. Sorghum hay, groundnut straw and compound concentrate mixture were oven dried at $70^{\circ} \mathrm{C}$ and finely ground in mill using $1 \mathrm{~mm}$ sieve. These ingredients were mixed in ratios of 30,30 and $40 \%$ to prepare total mixed ration (TMR). The TMR was prepared to meet nutrients requirement of dairy cow $(500 \mathrm{~kg})$ producing $12 \mathrm{~kg} 4 \%$ fat corrected milk (FCM) per day (NRC, 2001). The calculated nutritional values of TMR were $10.61 \%$ crude protein $(\mathrm{CP})$, 6.59\% digestible CP (DCP), 56.51\% total digestible nutrients, and $2.05 \mathrm{Mcal} \mathrm{ME} / \mathrm{kg}$ DM. The ingredients and TMR were analyzed for proximate constituents (AOAC, 1995), fiber fractions (Van Soest et al., 1991) and calcium and phosphorus.

The cellulase and xylanase was procured from $\mathrm{M} / \mathrm{s}$ Aumgene Bioscience Pvt. Ltd., Surat, Gujarat, India. The cellulase and xylanase contained 3000 and $200000 \mathrm{IU} / \mathrm{g}$, respectively as per manufacturer's labeling. The cellulase and xylanase were incorporated at $0+0$, $1000+2000, \quad 1000+3000, \quad 1000+4000$, $2000+4000, \quad 2000+6000, \quad 2000+8000$, $3000+6000, \quad 3000+9000, \quad 3000+12000$, $4000+8000, \quad 4000+12000, \quad 4000+16000$, $5000+10000, \quad 5000+15000, \quad 5000+20000$, $6000+12000,6000+18000$ and $6000+24000$ IU/kg TMR to ascertain effect on in vitro digestibility of DM and OM, in vitro NGP, ME content, MBP and EMP. The supplementation of cellulase was from 1000 , 2000, 3000, 4000, 5000 and $6000 \mathrm{IU} / \mathrm{kg}$ TMR with xylanase @ 2,3 and 4 time higher than cellulase in each TMR. The TMR with above 
levels of EFE was designated as $\mathrm{C} 0 \mathrm{X} 0, \mathrm{C} 1 \mathrm{X} 2$, C1X3, C1X4, C2X4, C2X6, C2X8, C3X6, C3X9, C3X12, C4X8, C4X12, C4X16, C5X10, C5X15, C5X20, C6X12, C6X18 and C6X24, respectively.

Rumen liquors were collected from three crossbred cows using stomach tube. The cows were fed individually to meet nutrients requirement (NRC, 2001) with free access to clean and wholesome water. The rumen liquor was strained through four layer muslin cloth and was termed strained rumen liquor (SRL). TMR with various levels of EFE were incubated for $48 \mathrm{~h}$ in quadruplet at $39 \pm 1^{\circ} \mathrm{C}$ for $48 \mathrm{~h}$ in a shaker twin water bath with $40 \mathrm{ml}$ of fresh McDougall buffer and $10 \mathrm{ml}$ SRL as per Menke et al., (1979). After incubation, the content of each syringe was filtered through dried and pre-weighed Gooch crucible, which was again dried and weighed. Simultaneously, the blank was also run without TMR sample in quadruplet. In vitro NGP was taken after subtracting gas production from blank. ME (Elghandour et al., 2015), MBP and EMP (Mir et al., 2015) was calculated as follows:

$\mathrm{ME}(\mathrm{MJ} / \mathrm{kg} \mathrm{DM})=2.20+0.136 \mathrm{Gp}+0.057$ $\mathrm{CP} \%,\left(\mathrm{R}^{2}=0.94\right)$

Where, $\mathrm{CP}$ is crude protein $\%$ and $\mathrm{Gp}$ is $\mathrm{ml}$ of net gas production from $200 \mathrm{mg}$ dry sample.

$\mathrm{MBP}=\{\mathrm{TDOM}-(2.2 \times$ net gas volume $)\}$ $\mathrm{TDOM}=($ Feed OM incubated-residue OM$)$.

Where, TDOM is total digestible OM.

$\mathrm{EMP}=\{\mathrm{TDOM}-(2.2 \times$ net gas volume $)\} \mathrm{x}$ $100 \div$ TDOM

Statistical analysis of the data on DM and OM digestibility, NGP, ME, MBP and EMP were carried out using Duncan's multiple range tests (SPSS 9.00 software) as per Snedecor and Cochran, (1994).

\section{Results and Discussion}

The proximate and fiber fractions composition of ingredients and TMR utilized for study are presented in Table 1. The TMR contained $10.35 \% \mathrm{CP}, 23.59 \% \mathrm{CF}, 53.34 \% \mathrm{NDF}$ and $29.92 \%$ ADF. In vitro DM and OM digestibility (\%), NGP, ME content, MBP and EMP of TMR supplemented with various levels of EFE are presented in Table 2.

\section{In vitro DM and OM digestibility (IVDMD and IVOMD) and net gas production (NGP)}

The digestibility of DM $(58.20 \pm 0.41 \%)$ and OM $\quad(58.79 \pm 0.51 \%)$ were significantly $(p<0.05)$ higher at C1X2 level of EFE incorporation in TMR and also at higher levels of incorporation. However, supplementation of cellulase and xylanase (EFE) at $3000+12000 \quad$ IU/kg TMR (C3X12) had improved $(\mathrm{p}<0.05) \mathrm{DM}$ and OM digestibility $(66.24 \pm 0.55 \%$ and $66.56 \pm 0.50 \%$, respectively) than lower levels of incorporation. Further increase in level of fibrolytic enzyme did not show beneficial effect on IVDMD and IVOMD. In vitro net gas production followed same trend.

Optimum higher in vitro $\mathrm{DM}$ and $\mathrm{OM}$ digestibility was reported by Lunagariya et al., (2017) on supplementation of EFE (1,4- $\beta$ glucanase $800,1(3), 4-\beta$ glucanase 700 and endo $1,4-\beta$ xylanase $2700 \mathrm{IU} / \mathrm{g}$ ) at $240 \mathrm{mg} / \mathrm{kg}$ TMR than lower $(0,40,60,80,100,120,140$, $160,180,200$ and $220 \mathrm{mg} / \mathrm{kg}$ TMR) or higher $(260,280,300,320,340,360,380$ and 400 $\mathrm{mg} / \mathrm{kg}$ TMR) dose rate for crossbred cows while in vitro gas production followed same trend. Rajamma et al., (2015) has incorporated EFE at $2.5 \mathrm{~g} / \mathrm{kg}$ DM TMR (roughage to concentrate ratio of $60: 40$ ) which resulted in higher $62.18 \% \quad(\mathrm{p} \leq 0.001) \quad$ IVDMD than control TMR (58.44\%). Similarly optimum and higher IVDMD and IVOMD of TMR 
(having 40:40:20 ratio of concentrate, wheat straw and green oats) was reported by Miachieo and Thakur (2007) on incorporated with fibrolytic enzymes @ $1.5 \mathrm{~g} / \mathrm{kg}$ than without or higher levels of EFE (3.0 g/kg DM) in TMR. Sipai et al., (2013) observed higher $(\mathrm{p} \leq 0.05)$ in vitro gas production $(96.33 \mathrm{ml}$ and $96.00 \mathrm{ml}$ ) when dry sorghum supplemented with EFE (1:1 mixture of neutral cellulase3000 units/g and fungal xylanase- 200000 units $/ g$ ) at 0.6 and $0.8 \%$, respectively, than dry sorghum supplemented without or with lower levels $(0.01,0.1,0.2,0.3$, and $0.5 \%)$ and higher levels $(0.9 \%$ and $1 \%)$ of fibrolytic enzymes.

Similarly, significant higher in vitro gas production observed on EFE supplementation in roughage diet (Gemeda et al., 2014), maize stover and sugarcane bagasse (Elghandour et al., 2016) and sorghum straw (Elghandour et al., 2013). These observations are in accordance with present study. However, when silage of corn (Faramarzi-Garmroodi et al., 2013; Elghandour et al., 2015), alfalfa and barley (Holtshausen et al., 2011) used as substrate for sole or ingredients of total mixed ration incubation, fermentation kinetics was not improved as silage considered as predigested feed.

\section{ME content of TMR}

Average ME content of TMR was 7.28 \pm 0.02 $\mathrm{MJ} / \mathrm{kg}$ DM. However, ME of TMR (6.95 \pm 0.02 $\mathrm{MJ} / \mathrm{kg}$ DM) significantly improved at minimum EFE level 1000+2000 cellulase and xylanase IU/kg (C1X2) than control (COX0).

The optimum and significantly higher ME content of TMR was $7.41 \pm 0.03 \mathrm{MJ} / \mathrm{kg} \mathrm{DM}$ when TMR was incorporated with EFE $3000+12000$ cellulase and xylanase IU/kg (C3X12). Further higher level of incorporation of EFE had shown no improvement in ME content of TMR. Lower ME content of TMR was observed than calculated $\mathrm{ME}(9.50 \mathrm{MJ} / \mathrm{kg}$ DM), however ME content of experimental TMR had shown incremental trend with increase in level of EFE incorporation.

Table.1 Composition of TMR and ingredients (\% on DM basis)

\begin{tabular}{|c|c|c|c|c|}
\hline Parameters & TMR & $\begin{array}{l}\text { Concentrate } \\
\text { mixture }\end{array}$ & Sorghum hay & $\begin{array}{c}\text { Groundnut } \\
\text { straw }\end{array}$ \\
\hline CP & $10.35 \pm 0.34$ & 15.06 & 6.06 & 8.98 \\
\hline EE & $3.38 \pm 0.08$ & 6.42 & 1.62 & 1.04 \\
\hline $\mathrm{CF}$ & $23.59 \pm 0.58$ & 10.23 & 34.55 & 30.32 \\
\hline NFE & $52.21 \pm 0.36$ & 58.49 & 48.31 & 47.89 \\
\hline Total ash & $10.29 \pm 0.12$ & 9.80 & 9.46 & 11.77 \\
\hline Silica & $2.03 \pm 0.38$ & 1.08 & 3.24 & 2.03 \\
\hline Calcium & $1.01 \pm 0.25$ & 1.31 & 0.66 & 0.91 \\
\hline Phosphorus & $0.45 \pm 0.12$ & 0.65 & 0.28 & 0.37 \\
\hline NDF & $53.34 \pm 1.21$ & 26.48 & 72.46 & 69.96 \\
\hline ADF & $29.92 \pm 0.29$ & 11.19 & 48.21 & 36.45 \\
\hline
\end{tabular}

TMR=total mixed ration, $\mathrm{DM}=$ Dry matter, $\mathrm{CP}=$ Crude protein, $\mathrm{EE}=$ Ether extract, $\mathrm{CF}=$ Crude fibre, $\mathrm{NFE}=\mathrm{Nitrogen}$ free extract, $\mathrm{NDF}=$ Neutral detergent fibre, $\mathrm{ADF}=$ Acid detergent fibre 
Table.2 Average IVDMD, IVOMD, IVNGP, ME, MBP, EMP and PF of TMR containing different levels of Exogenous fibrolytic enzymes

\begin{tabular}{|c|c|c|c|c|c|c|}
\hline \multirow[t]{2}{*}{ TMR } & \multicolumn{6}{|c|}{ Particulars } \\
\hline & IVDMD\% & IVOMD\% & $\begin{array}{c}\text { IVNGP (ml/500 } \\
\text { mg) }\end{array}$ & ME (MJ/kg DM) & $\begin{array}{c}\text { MBP (mg/500 mg } \\
\text { TMR) }\end{array}$ & EMP \\
\hline COXO & $55.92^{a} \pm 0.28$ & $56.47^{\mathrm{a}} \pm 0.16$ & $66.15^{\mathrm{a}} \pm 0.34$ & $6.79^{a} \pm 0.02$ & $120.65^{\mathrm{a}} \pm 0.16$ & $42.73^{a} \pm 0.14$ \\
\hline C1X2 & $58.20^{b} \pm 0.41$ & $58.79^{b} \pm 0.51$ & $68.80^{b} \pm 0.29$ & $6.95^{b} \pm 0.02$ & $125.76^{b} \pm 2.05$ & $42.78^{a} \pm 0.34$ \\
\hline C1X3 & $59.95^{c} \pm 0.24$ & $60.58^{c} \pm 0.27$ & $70.25^{c} \pm 0.21$ & $7.04^{c} \pm 0.01$ & $131.16 \pm 1.43$ & $43.30^{a b c} \pm 0.30$ \\
\hline C1X4 & $60.65^{\mathrm{cd}} \pm 0.26$ & $61.30^{c d} \pm 0.37$ & $70.83^{c d} \pm 0.40$ & $7.07^{\mathrm{cd}} \pm 0.02$ & $133.35^{\mathrm{cd}} \pm 1.11$ & $43.51^{a b c} \pm 0.17$ \\
\hline $\mathrm{C} 2 \mathrm{X} 4$ & $61.49^{d e} \pm 0.30$ & $62.03^{\mathrm{de}} \pm 0.32$ & $71.85^{\mathrm{de}} \pm 0.53$ & $7.13^{\mathrm{de}} \pm 0.03$ & $134.52^{\mathrm{cd}} \pm 1.33$ & $43.37^{a b c} \pm 0.34$ \\
\hline C2X6 & $62.43^{\mathrm{e}} \pm 0.22$ & $62.76^{\mathrm{e}} \pm 0.24$ & $72.88^{\mathrm{ef}} \pm 0.18$ & $7.19^{\mathrm{ef}} \pm 0.01$ & $135.66^{\mathrm{d}} \pm 0.96$ & $43.23^{\mathrm{abc}} \pm 0.16$ \\
\hline C2X8 & $62.53^{\mathrm{e}} \pm 0.31$ & $62.88^{\mathrm{e}} \pm 0.21$ & $73.20^{\mathrm{ef}} \pm 0.34$ & $7.21^{\mathrm{ef}} \pm 0.02$ & $135.45^{d} \pm 0.64$ & $43.09^{a b c} \pm 0.16$ \\
\hline C3X6 & $63.96^{\mathrm{f}} \pm 0.39$ & $64.23^{f} \pm 0.68$ & $74.10^{\mathrm{fg}} \pm 0.41$ & $7.27^{\mathrm{fg}} \pm 0.02$ & $140.02^{\mathrm{e}} \pm 2.51$ & $43.59^{b c} \pm 0.34$ \\
\hline C3X9 & $64.50^{f} \pm 0.39$ & $64.99^{f} \pm 0.35$ & $74.88^{\mathrm{g}} \pm 0.34$ & $7.32^{\mathrm{fg}} \pm 0.02$ & $141.91^{\mathrm{ef}} \pm 0.92$ & $43.67^{b c} \pm 0.06$ \\
\hline C3X12 & $66.24^{\mathrm{g}} \pm 0.55$ & $66.56^{\mathrm{g}} \pm 0.50$ & $76.48^{h} \pm 0.45$ & $7.41^{h} \pm 0.03$ & $145.86^{\mathrm{fg}} \pm 1.47$ & $43.83^{b c} \pm 0.14$ \\
\hline C4X8 & $66.27^{g} \pm 0.18$ & $66.60^{\mathrm{g}} \pm 0.13$ & $76.88^{h} \pm 0.25$ & $7.44^{h} \pm 0.02$ & $145.06^{\mathrm{fg}} \pm 0.23$ & $43.56^{b c} \pm 0.09$ \\
\hline C4X12 & $66.26^{g} \pm 0.48$ & $66.83^{\mathrm{g}} \pm 0.48$ & $76.68^{h} \pm 0.40$ & $7.42^{h} \pm 0.02$ & $146.73^{g} \pm 1.41$ & $43.91^{b c} \pm 0.11$ \\
\hline C4X16 & $66.43^{\mathrm{g}} \pm 0.30$ & $67.04^{g} \pm 0.18$ & $76.95^{h} \pm 0.41$ & $7 . .44^{h} \pm 0.02$ & $147.10^{g} \pm 0.65$ & $43.88^{b c} \pm 0.21$ \\
\hline C5X10 & $66.38^{\mathrm{g}} \pm 0.36$ & $66.69^{g} \pm 0.44$ & $76.90^{h} \pm 0.40$ & $7.44^{h} \pm 0.02$ & $145.45^{f g} \pm 1.50$ & $43.62^{b c} \pm 0.22$ \\
\hline C5X15 & $66.49^{\mathrm{g}} \pm 0.62$ & $67.07^{g} \pm 0.53$ & $76.80^{h} \pm 0.69$ & $7.43^{h} \pm 0.04$ & $147.59^{g} \pm 1.03$ & $44.02^{c} \pm 0.11$ \\
\hline C5X20 & $66.30^{\mathrm{g}} \pm 0.69$ & $66.88^{\mathrm{g}} \pm 0.64$ & $76.63^{h} \pm 0.98$ & $7.42^{h} \pm 0.06$ & $147.07^{g} \pm 1.71$ & $43.99^{c} \pm 0.38$ \\
\hline C6X12 & $66.37^{\mathrm{g}} \pm 0.24$ & $66.89^{g} \pm 0.31$ & $76.98^{h} \pm 0.49$ & $7.44^{h} \pm 0.03$ & $146.30^{g} \pm 1.85$ & $43.74^{b c} \pm 0.42$ \\
\hline C6X18 & $66.49^{\mathrm{g}} \pm 0.33$ & $66.84^{\mathrm{g}} \pm 0.36$ & $76.78^{h} \pm 0.63$ & $7.43^{h} \pm 0.04$ & $146.50^{g} \pm 0.87$ & $43.84^{b c} \pm 0.25$ \\
\hline C6X24 & $66.47^{\mathrm{g}} \pm 0.37$ & $66.89^{g} \pm 0.44$ & $77.18^{h} \pm 0.32$ & $7.45^{h} \pm 0.02$ & $145.79^{\mathrm{fg}} \pm 1.67$ & $43.59^{b c} \pm 0.25$ \\
\hline $\begin{array}{l}\text { Gen. } \\
\text { Mean }\end{array}$ & 63.86 & 64.33 & 74.27 & 7.28 & 140.10 & 43.54 \\
\hline SEM & 0.38 & 0.37 & 0.38 & 0.02 & 0.95 & 0.06 \\
\hline
\end{tabular}

$\mathrm{a}, \mathrm{b}, \mathrm{c}, \mathrm{d}, \mathrm{e}, \mathrm{f}, \mathrm{g}, \mathrm{h}$ Means with different superscripts in a column for a parameter differ significantly $(\mathrm{p}<0.05)$.

IVDMD=In vitro dry matter, IVOMD=In vitro organic matter, IVNGP=In vitro net gas production, ME=metabolizable energy, MBP=Microbial biomass production, EMP=Efficiency of microbial biomass production 
The ME content of TMR was linearly improved on incorporation of EFE from 40 to $240 \mathrm{mg} / \mathrm{kg}$ and shown no improvement on further incorporation of EFE from 240 to 400 $\mathrm{mg} / \mathrm{kg}$ (Lunagariya et al., 2017), whereas quadratic $(\mathrm{p}<0.05)$ improvement has been observed when sorghum incubated with exogenous enzymes mixture at $0,6,12$ and 24 $\mathrm{mg} / \mathrm{g}$ DM levels (Elghandour et al., 2013). Similar values and non-significant $(\mathrm{p}=0.0734)$ improvement in ME content of TMR as 6.88, $6.89,6.76$ and $7.12 \mathrm{MJ} / \mathrm{kg} \mathrm{DM}$, respectively observed by Elghandour et al., (2015) when the TMR having 50\% maize silage $(\mathrm{F})$ and $50 \%$ concentrate incubated without EFE, with cellulase $1 \mu \mathrm{l} / \mathrm{g}(\mathrm{C}, 0.033 \mathrm{unit} / \mathrm{g})$, xylanase 1 $\mu \mathrm{l} / \mathrm{g}$ (X, 0.038 unit/g) and a mixture of cellulase and xylanase (XC, 1:1, v:v).

\section{MBP and EMP}

The MBP (mg/500 mg TMR) increased significantly at cellulose + xylanase $1000+2000 \mathrm{IU} / \mathrm{kg}$ TMR (125.76 \pm 2.05$)$ than control (120.65 \pm 0.16$)$. The linear improvement trend was observed with increasing level of cellulase and xylanase, but the optimum and significantly higher MBP $(146.73 \pm 1.41)$ was achieved at $4000+12000$ IU cellulase and Xylanase/kg TMR. The further higher levels of EFE were without significant improvement effect on MBP. The efficiency of microbial biomass production (EMP) was significantly higher at 3000+6000 IU cellulase and xylanase $/ \mathrm{kg}$ TMR, however best efficiency was observed at C5X15 and C5X20 TMR supplemented with fibrolytic enzymes. The MBP values observed in present experiment are within the physiological range (100- $470 \mathrm{~g} / \mathrm{kg}$ TDOM) for mixed diets (Thirumalesh and Krishnamoorthy, 2013). Lunagariya et al., (2017) also reported improved trend in microbial biomass production on incorporation of EFE from 40 to $240 \mathrm{mg} / \mathrm{kg}$ TMR and further higher levels were without improvement. Elghandour et al., (2015) reported non-significant $\quad(\mathrm{p}=0.6602)$ difference in MBP when TMR (50\% each of maize silage and concentrate) was incubated with cellulase $1 \mu \mathrm{l} / \mathrm{g} \quad(\mathrm{C}, 0.033 \mathrm{unit} / \mathrm{g})$, xylanase $1 \mu \mathrm{l} / \mathrm{g}(\mathrm{X}, 0.038 \mathrm{unit} / \mathrm{g})$, a mixture of cellulase and xylanase (XC, 1:1, v:v), and control TMR, this may be due to use of predigested roughage (maize silage).

When TMR incorporated with cellulase and xylanase @ 3000+ 12000 IU/kg in vitro DM and OM digestibility and IVNGP was found to be significant and optimum $(66.24 \pm 0.55 \%$, $66.56 \pm 0.50 \%$ and $76.48 \pm 0.45 \mathrm{ml} / 500 \mathrm{mg}$, respectively) than control TMR without EFE or other levels of EFE. The optimum and higher $\mathrm{ME}(7.41 \pm 0.03 \mathrm{MJ} / \mathrm{kg} \mathrm{DM})$ also observed at same level of fibrolytic enzymes. The MBP (146.73 $\pm 1.41 \mathrm{mg} / 500 \mathrm{mg}$ TMR) and EMP (44.02 \pm 0.11$)$ was significant higher $(\mathrm{p}<0.05)$ at incorporation cellulase and xylanase @ 4000+12000 and 5000+15000 IU/kg TMR in comparison to TMR without EFE or lower levels. Further higher levels of EFE did not shown improvement. The digestibility of DM and OM was improved positive and linearly with increment in NGT. The same correlations of gas production with digestibility of DM and OM under in vitro study were also reported by Blair (2011) and Mir et al., (2015). The digestibility, gas production, ME, MBP and EMP was improved owing to stimulatory effect on rumen microbiota (Nsereko et al., 2002), synergetic effect of EFE and rumen microbe (Morgavi et al., 2000), enhance attachment of rumen microbial to feed particles (Yang et al., 1999) and degrade complex fraction to simple molecules making them more available to rumen microbes by EFE (Azzaz et al., 2013).

An improved $(\mathrm{p}<0.05)$ in vitro digestibility of DM (58.20\%), OM (58.79\%), and NGP (68.80 ml/500 mg TMR), ME (6.95 MJ/kg $\mathrm{DM}$ ) and MBP (125.76 mg/500 mg TMR) 
was observed when cellulase and xylanase was supplemented at $1000+2000 \mathrm{IU} / \mathrm{kg}$ TMR in comparison to control whereas EMP was significantly higher at C3X6 TMR. The incorporation of cellulase and xylanase @ 3000+12000 IU/kg TMR resulted in optimum and significantly $(\mathrm{p}<0.05)$ higher in vitro digestibility of DM (66.24\%) and OM (66.56\%); NGP (76.48 ml/500mg) and ME (7.41 MJ/kg DM) compared to lower levels, whereas MBP (146.73 mg/500 mg TMR) and EMP (44.02) was optimum and significant at C4X12 and C5X15 TMR, respectively. MBP and EMP were also better at C3X12 TMR level. The digestibility, gas production and nutritive values of TMR did not show improvement with higher incorporation of cellulase and xylanase. The levels of cellulase and xylanase @ 3000+12000 IU/kg TMR were found suitable for milk production study in crossbred dairy cows.

\section{References}

AOAC. 1995. Official Methods of Analysis. 16th ed. Association of Official Analytical Chemists, Washington, DC.

Azzaz, H.H., Murad, H.A., Kholif, A.M., Morsy, T.A., Mansour, A.M. and ElSayed, H.M. 2013. Increasing nutrients bioavailability by using fibrolytic enzymes in dairy buffaloes feeding. $J$. Biosci. 13: 234-241.

Beauchemin, K.A. and Rode, L.M. 1996. Use of Feed Enzymes in Ruminant Nutrition. Proceedings in Canadian Society of Animal Science. Annual Meeting, Lethbridge, Alberta. p 103140.

Blair, R. 2011. Ingredients for Organic Diets: In Nutrition and Feeding of Organic Cattle. CAB International, Oxfordshire, UK. p135.

Elghandour, M.M.M., Kholif, A.E., MárquezMolina, O., Vázquez-Armijo, J.S., Puniya, A.K. and Salem, A.Z.M. 2015.
Influence of individual or mixed cellulase and xylanase mixtures on in vitro rumen gas production kinetics of total mixed rations with different maize silage and concentrate ratios. Turk. J. Vet. Anim. Sci. 39: 1-8.

Elghandour, M.M.Y., Kholif, A.E., Hernández, J., Mariezcurrena, M.D., López, S., Camacho, L.M., Márquez, O. and Salem, A.Z.M. 2016. Influence of the addition of exogenous xylanase with or without pre-incubation on the in vitro ruminal fermentation of three fibrous feeds. Czech J. Anim. Sci. 61(6): 262272.

Elghandour, M.M.Y., Salem, A.Z.M., Gonzalez- Ronquillo, M., Bórquez, J.L., Gado, H.M., Odongo, N.E. and Penuelas, C.G. 2013. Effects of exogenous enzymes on in vitro gas production kinetics and ruminal fermentation of four fibrous feeds. Anim. Feed Sci. Technol. 179: 46-53.

Faramarzi-Garmroodi, A., Mesgaran, M.D., Parand, E. and Vakili, A.R. 2013. In vitro effect of increasing levels of Natuzyme ${ }^{\circledR}$ on fermentation responses of corn silage based diet. Annu. Rev. Res. Biol. 3(4): 1066-1073.

Gemeda, B.S., Hassen, A. and Odongo, N.E. 2014. Effect of fibrolytic enzyme products at different levels on in vitro ruminal fermentation of low quality feeds and total mixed ration. J. Anim. Plant Sci. 24(5): 1293-1302.

Holtshausen, L., Chung, Y.H., GerardoCuervo, H., Oba, M. and Beauchemin, K.A. 2011. Improved milk production efficiency in early lactation dairy cattle with dietary addition of a developmental fibrolytic enzyme additive. J. Dairy Sci. 94: 899-907.

Krause, D. O., Denman, S. T., Mackie, R. I., Morrison, M., Rae, A. L, Attwood, G. T. and McSweeney, C. S. 2003. Opportunities to improve fibre 
degradation in the rumen. Microbiology, ecology and genomics. FEMS Microbiol. Rev. 27: 663-693.

Lunagariya, P. M., Gupta, R. S. and Parnerkar, S. 2017. In vitro evaluation of total mixed ration supplemented with exogenous fibrolytic enzymes for crossbred cows. Veterinary World. 10(3): 281-285.

Makkar, H.P.S. 2004. Recent advances in the in vitro gas method for evaluation of nutritional quality of feed resources. In: Assessing Quality and Safety of Animal Feeds. Food and Agriculture Organization of United Nations, Rome. p 55-88. Available from: http://www. fao.org/docrep/007/y5159e/y5159e05. htm. Downloaded on 28-4-2016.

Menke, K.H., Rabb, L., Salewski, A., Steingass, H., Fritz, D. and Schneiser, W. 1979. The estimation of the digestibility and metabolizable energy content of ruminant feedstuffs from the gas production when they are incubated with rumen liquor in vitro. J. Agric. Sci. 93: 217-222.

Mertens, D. R. 1997. Creating a system for meeting the fibre requirements of dairy cows. J. Dairy Sci. 80: 1463-1481.

Miachieo, K. and Thakur, S.S. 2007. Effect of exogenous fibrolytic enzymes on the productive performance of lactating Sahiwal cows. Indian J. Anim. Nutr. 24(1): 27-30.

Mir, M.A., Sharma, R.K., Rastogi, A. and Barman, K. 2015. Effect of incorporation of walnut cake (Juglans regia) in concentrate mixture on degradation of dry matter, organic matter and production of microbial biomass in vitro in goat. Vet. World. 8(10): 1172-1176.

Morgavi, D.P., Beauchemin, K.A., Nsereko, V.L. and Rode, L.M. 2000. Synergy between ruminal fibrolytic enzymes and enzymes from Trichoderma longibrachiatum in degrading fibre substrates. J. Dairy Sci. 83: 1310-1321.

Morsy, T.A., Kholif, A.E., Kholif, S.M., Kholif, A.M., Sun, X. and Salem, A.Z.M. 2015. Effects of two enzyme feed additives on digestion and milk production in lactating Egyptian buffaloes. Ann. Anim. Sci., 16(1): 209222.

NRC. 2001. Nutrient Requirements of Dairy Cattle. 7th Revised Edition. Subcommittee on Dairy Cattle Nutrition, Committee on Animal Nutrition, National Research Council, National Academy Press, Washington, DC. Available from: http://www.nap. edu/catalog/9825.htm. Accessed on 2508-2016.

Nsereko, V.L., Beauchemin, K.A., Morgavi, D.P., Rode, L.M., Furtado, A.F., McAllister, T.A., Iwassa, A.D., Yang, W.Z. and Wang, Y. 2002. Effect of fibrolytic enzyme preparation from Trichoderma longibrachiatum on the rumen microbial population of dairy cows. Can. J. Microbiol. 48: 14-20.

Rajamma, K., Kumar, D.S., Rao, E.R. and Nath, D.N. 2014. Nutrient utilization in buffalo bulls fed total mixed rations supplemented with exogenous fibrolytic enzymes. Indian J. Anim. Nutr. 31(3): 213-217.

Rajamma, K., Kumar, D.S., Rao, E.R. and Nath, D.N. 2015. In vitro evaluation of total mixed ration containing different roughage-concentrate ratios supplemented with or within fibrolytic enzymes. Anim. Sci. Report. 9(2): 6369.

Romney, D. L. \& Gill, M. 2000. Forage Evaluation for Efficient Ruminant Livestock Production. Eds. Givens, D. L.; Owen, E., Axford, R. F. E. \& Omed, H. M. CAB international, pp. 43-62.

Sipai, S.H., Dutta, K.S., Savsani, H.H., Murthy, K.S., Vataliya, P.H., Chavda, 
J.A. and Gajera, A.P. (2013) Inclusion of different exogenous fibrolytic enzymes to dry jowar fodder and their effect on in vitro total gas production. Vet. World. 6(11): 839-843.

Snedecor, G.W. and Cochran, W.G. 1994. Statistical Methods. 8th ed. Affiliated East-West Spress Pvt. Ltd., New Delhi.

Thirumalesh, T. and Krishnamoorthy, U. 2013. Rumen microbial biomass synthesis and its importance in ruminant production. Int. J. Livest. Res. 3(2): 526.

Van de Vyver, W.F.J. and Cruywagen, C.W.C. 2013. Exogenous fibrolytic enzymes to unlock nutrients: Histological investigation of its effects on fibre degradation in ruminants. $S$. Afr. J. Anim. Sci. 43(5): S54-S59.

Van Soest, P. J. 1994. Nutritional Ecology of the Ruminant. Cornell University Press, Ithaca, NY, USA.

Van Soest, P.J., Robertson, J.B. and Lewis, B.A. 1991. Methods of dietary fiber, neutral detergent fiber and non starch polysaccharides in relation to animal nutrition. J. Dairy Sci. 74: 3583-3597.

Varga, G. A. and Kolver, E. S. 1997. Microbial and animal limitations to fiber digestion and utilization. J. Nutr. 127: 819-824.

Wang, Y., Ramirez-Bribiesca, J.E., Yanke, L.J., Tsang, A. and McAllister, T.A. 2012. Effect of exogenous fibrolytic enzyme application on the microbial attachment and digestion of barley straw in vitro. Asian Australas. J. Anim. 25(1): 66-74.

Weimer, P. J., Russell, J. B. and Muck, R. E. 2009. Lessons from the cow: What the ruminant animal can teach us about consolidated bioprocessing of cellulosic biomass. Bioresour. Technol. 100: 5323-5331.

Yang, W.Z., Beauchemin, K.A. and Rode, L.M. 1999. Effects of an enzyme feed additive on extent of digestion and milk production of lactating dairy cows. $J$. Dairy Sci. 82: 391-403.

\section{How to cite this article:}

Lunagariya, P.M., S.V. Shah, B.R. Devalia, A.C. Patel and Pandya, P.R. 2018. An In vitro Dose Optimization of Exogenous Fibrolytic Enzymes in Total Mixed Ration for Crossbred Cows. Int.J.Curr.Microbiol.App.Sci. 7(10): 330-338. doi: https://doi.org/10.20546/ijcmas.2018.710.035 